\title{
FAMILY FUNCTIONING AND SELF-SILENCING OF STUDENTS
} UDC 159.942.072-057.875:316.356.2

\author{
Ivana Janković ${ }^{1}$, Jelisaveta Todorović ${ }^{1}$, Violeta Arnaudova ${ }^{2}$ \\ ${ }^{1}$ University of Niš, Faculty of Philosophy, Department of Psychology, Niš, Serbia \\ ${ }^{2}$ SS. Cyril and Methodius University, Faculty of Philosophy, \\ Institute of Psychology, Skopje, Macedonia
}

\begin{abstract}
Starting from the main hypothesis of the Circumplex Model that the balanced levels of cohesion and flexibility are the most appropriate for family functioning, and that unbalanced levels of cohesion and flexibility are related to problematic family functioning, in this paper we wanted to investigate in what way these dimensions of family functioning are related to self-silencing. In this model, cohesion is defined as an emotional relationship between family members, and flexibility is defined as a quality and expression of leadership and organization. Self-silencing is related to the cognitive schema of creating and maintaining intimate relations in a way that a person is passive, that he/she suppresses his/her feelings, opinion and actions in order to satisfy the needs of people close to them.

The research was conducted on a sample of 250 Serbian and Macedonian students. The following instruments were used in this research: Silencing the Self Scale and FACES IV, which consists of three scales that measure Cohesion (Disengaged, Balanced Cohesion and Enmeshed), three scales that measure Flexibility (Rigid, Balanced Flexibility and Chaotic), Scale for the Assessment of Family Communication, which is defined as the skill of positive communication and it is considered to be a mitigating dimension and it helps families change their levels of cohesion and flexibility, and the Scale for the Assessment of Family Satisfaction.

Self-silencing is in a positive correlation with unbalanced levels of cohesion, with disengaged family relations $(r=.195, p=.002)$ and with enmeshed (entangled) family relations $(r=.332, p=.000)$. Self-silencing is in a positive correlation with Unbalanced levels of flexibility, with rigid $(r=.243, p=.000)$ and chaotic family relations $(r=.217, p=.001)$.

Balanced Cohesion, as the indicator of healthy family functioning, is related to a lower level of self-silencing of family members, that is, in such families the members can openly speak about their needs, feelings and opinions without fear that it would jeopardize the needs of other family members. The members of families with a very low or very high cohesion and flexibility conceal their needs and desires in order to satisfy the needs of other members.
\end{abstract}

Key words: family, cohesion, flexibility, self-silencing, students.

Received February 8, 2017 / Accepted June 26, 2017

Corresponding author: Ivana Janković

University of Niš, Faculty of Philosophy, Cirila i Metodija 2, 18000 Niš, Serbia

E-mail: ivana.jankovic@filfak.ni.ac.rs 


\section{INTRODUCTION}

The family can be seen as the primary group in which family members, primarily parents, provide an encouraging atmosphere for the development of its members, so that every member would be able to fulfill his/her developmental needs and tasks. Above all, the family should be a safe place, a place where the members could feel free to express their needs, opinions and feelings without fear that other family members would judge or reject them because of that. This definition of a family is not valid for every family. We may witness that not all families in our surroundings are like that. In contrast to functional, there are also dysfunctional families. Functional families are families that respect individuality, where family members have the capability to determine closeness and distance and where there is a belief of family members that their needs and interests are equally important as the needs and interests of other members. On the other hand, dysfunctional families lack clear and open communication, there are constant conflicts, family members are distanced from one another, and they do not share their opinions and needs with other family members because they fear that it can even further worsen family relations. Dana Jack (1991) introduced the term self-silencing to explain the tendency to hide one's own feelings and needs in order to maintain the emotional relations and existing relations with people close to them.

The goal of this paper was to investigate how much family function and dysfunction are related to self-silencing and what the nature of that relation is. For the assessment of family functionality, we relied on the Circumplex Model, created by Olson and associates (Olson, Gorall and Tiesel 2006).

\section{THE CIRCUMPLEX MODEL OF FAMILY FUNCTIONING}

The Circumplex Model (Olson 1986; Olson 2011; Olson and Gorall 2006) consists of three key concepts for understanding family functioning: Cohesion, Flexibility (adaptability) and Communication.

Cohesion is defined as the emotional relationship family members have with one another. According to Olson (Olson 2011; Perosa and Perosa 2001; Olson and Gorall 2006), cohesion is focused on how family makes a balance between unity and separation. In related family systems, there is a sense of emotive closeness and loyalty to the spouse. Families characterized by an appropriate level of cohesion spend together as much time as possible, they jointly participate in making family decisions, they have a strong emotional connection and they are very close. The emphasis here is on unity. Olson thinks that, in contrast to that, unbalanced levels of cohesion are at their extremes (very low or very high). Disengaged family systems often possess extreme emotional detachment. The members of these family systems engage very little in any form of relation with other family members, so what is encouraged in these people is autonomy and independence at the expense of closeness and unity. A lack of cohesion exists in families in which the members are more directed at (focused on) themselves, their own life and friends, they value their personal space more than the community and they spend little time together. An extremely high cohesion is characterized by a high level of entanglement and connection between family members with minimum individuality for each of them. Family cohesion is measured by the investigation of emotional relations, boundaries, coalitions, the decision-making process, interests, and reactions (Milojković, Srna i Mićović 1997). 
The next dimension that is very significant for family functioning is adaptability, that is, flexibility. Flexibility used to be defined in the past as the amount of change in family leadership, in relations among the roles and in the rules related to relations. The new definition of family flexibility is the quality and expression of leadership and organization, and the relations among the roles and negotiations (Olson and Gorall 2006, 3). Family flexibility is manifested in how much the assertive family members are involved in mutual relations, the amount of control in the family, disciplinary actions in the family, manner of negotiating, stiffness in the way in which family roles have been divided, as well as in the nature and manner of implementation of rules in the family. The balance of the adaptability dimension represents a family organization characterized by healthy levels of structure and flexibility (Perosa and Perosa 2001, 407). Functional flexibility implies the existence of a stabile structure and certain rituals, where there is also the possibility of change - adaptability, which implies the adjustment to the changed circumstances and developmental imperatives in family life cycles, especially when crises are in question. Unbalanced family systems lean upon being either rigid or chaotic. A rigid relationship is the one in which one person is in charge, where that person possesses a high level of control. The rules are strictly defined and they never change. A chaotic relationship is the one in which leadership is either not permanent (unstable) or limited. Rigid families are not able to change their structure of power and the patterns of interaction in a proper manner in order to adjust to the demands and challenges they face. Chaotic family systems are characterized by disorganization and inconsistency; the roles are not clear and they may be changed, and there are no clear rules. Chaotic families are characterized by too much freedom and the lack of clear ideas how and when the power structure should be changed and who takes over which role at what time (Olson and Gorall 2006; Olson 2011; Perosa and Perosa 2001).

Communication is the third important dimension in the Model. Communication is defined as the skill of positive communication used by a couple or a family system. Communication is considered to be a mitigating dimension that helps families change their levels of cohesion and flexibility (Olson 2011; Olson and Gorall 2006). This dimension is assessed through the listening and speaking skills of family members, the clarity of speech, the possibility to follow the continuity of conversation, as well as through appreciation and respect for others as opposed to putting oneself first (Mitic 1997). The characteristics of adequate communication, which allows the family to reach an optimal level of cohesion and flexibility, were the following: clear and congruent content of the message, empathy, active listening, provision of support and efficiency in solving problems in family transactions (Olson et al. 1983, according to: Perosa and Perosa 2001, 407). On the other hand, inadequate communication would have the following characteristics: incongruent content that disqualifies the other participant in the conversation (interlocutor), lack of empathy and support for the interlocutor, criticism, inefficiency in solving problems as well as contradictory and ambiguous messages. Such communication prevents family members from exchanging opinions and feelings, and the consequence is a reduced possibility for changing the level of cohesion and flexibility (Riesch, Henriques and Chanchong 2003, according to: Zotović, Telečki, Mihić i Petrović 2008, 147). In that way, according to this model, balanced couples and families should have more positive communication skills than extreme families.

The main hypothesis of the Circumplex Model is that balanced levels of cohesion and flexibility (from a lower to higher level) are the most appropriate for healthy family 
functioning, whereas unbalanced levels of cohesion (disengaged and enmeshed) and unbalanced levels of flexibility (rigid and chaotic) are associated with problematic family functioning (Olson and Gorall 2006, 3).

\section{SILENCING THE SELF THEORY}

Silencing the self theory is based on a longitudinal study of clinically depressed women's descriptions of their experiences (Jack 1991), including their understanding of what led up to their depression. The women detailed how they began to silence or suppress certain thoughts, feelings, and actions that they thought would contradict their partner's wishes. They did so to avoid conflict, to maintain a relationship, and/or to ensure their psychological or physical safety. They described how silencing their voices led to a loss of self and a sense of being lost in their lives (Jack and Ali 2010).

Self-silencing relates to the cognitive schema of creating and maintaining a safe intimate relation in a way that a person is passive, that the person suppresses his/her feelings, opinions and actions in order to satisfy the needs of people close to them (Jack 1991).

Although Silencing the Self scale (STSS) puts an emphasis on cognitive schemas, it is not based on the cognitive deficit model (Beck, Rush, Shaw and Emery 1979; according to: Jack and Dill 1992, 98) or on the characterological/personal model (Blatt, Quinlan, Chevron, McDonald and Zuroff 1982; according to: Jack and Dill 1992, 98) which point to stable and universal aspects of personality and their interaction with episode stressors in the surroundings. It would be better to say that STSS follows the presuppositions of phenomenological psychology (Mead 1956, according to: Jack and Dill 1992, 99), also contained in the theory of socially constructed reality (Berger, Luckmann1967, according to: Jack and Dill 1992, 99): categories through which people actively interpret their world, govern their behavior, as well as estimate themselves as socially constructed and in accordance with social institutions and contexts. The gender-specific aspect of socialization and material social power are reflected in these social categories of opinion.

STSS should significantly correlate with the depressive score on the sample of females who share a similar social and relational context. Self-silencing should be significantly different between the groups whose social and relational contexts are significantly different. Although STS primarily measures normative beliefs which are considered to be socially desirable than reflects the level of psychological stress and functioning, higher scores should not be interpreted as worse functioning but as if they reflect a higher pressure to meet the norms of "a good wife". The pressure can originate from a long-term situation (parental model) or from external situational factors (social context, including specific relations) (Jack and Dill 1992, 99).

Apart from the qualitative study which was the foundation for the development of the Silencing the Serf Theory (Jack 1991), there are no data about the research of the connection (interrelationship) between the perception of parents and self-silencing. Jack found that 11 out of 12 women she interviewed described their mothers as submissive and self-disparaging. These women said that they had often been a source of emotional support to their mothers and that, by providing support, they had learned to deny their own feelings and to be more responsive to others (Thompson, Whiffen and Aube 2001, 505).

Self-silencing can be seen as an interpersonal style which is developed as a result of the attempt to satisfy someone powerful, but to reject a more significant other, such as a 
critical partner or a cold parent (Thompson, Whiffen and Aube 2001, 506). This paper should contribute to the illumination of self-silencing relations and perception of family relations, that is, to provide an answer to the question whether a certain perception of family relations also contributes to self-silencing. We assume that self-silencing can also be a means of security and warmth by the parents and a means to avoid rejection by hiding one's own feelings and desires in order to fulfill these objectives.

\section{RESEARCH OBJECTIVES}

In this paper, we investigate:

- the link between self-silencing and cohesion of the family system;

- the link between self-silencing and flexibility of the family system;

- the link between self-silencing and family communication;

- the link between self-silencing and family satisfaction

- the perception of family relations depending on the participant's gender, place of residence, and household income.

\section{INSTRUMENTS}

A modified Silencing the Self Scale was used in this paper (Nekić, Lacković Grgin i Penezić 2004) and it had 31 items in contrast to the original scale which has 34 items (Jack 1991). Items 1, 21 and 24 were discarded due to a low saturation factor and a low correlation with the final result. Afterwards, the analysis was repeated for common factors with one factor in focus (one tested factor). That factor explains 25.67 per cent of the common variance (Nekić, LackovićGrgin i Penezić 2004). The scale is Likert type scale from 1 to 5, and an example of an item would be 'In an intimate relationship I do not express my feelings when I am positive they will cause disagreement'.

FACES IV (Olson, Gorall and Tiesel 2006), the scale for the measurement of family relations consists of:

Three scales that measure the dimensions of Cohesion:

- Disengaged - An example of an item: `Our family rarely does anything together`.

- Balanced Cohesion - An example of an item: 'Our family has a good balance regarding separation and anxiety”.

- Enmeshed - An example of an item: `Family members are too dependent on each other'.

Three scales that measure the dimensions of Flexibility:

- Rigid - An example of an item: `As soon as a decision is made, it is difficult to change it'.

- Balanced Flexibility - An example of an item: - 'In our family there are clear rules and roles'.

- Chaotic - An example of an item: 'It is difficult to distinguish who is the leader in our family`.

All scales for measuring cohesion and flexibility contain 7 items each.

The Scale for the Assessment of Family Communication contains 10 items, and an example of an item would be: 'Family members can talk peacefully to each other about their problems`. 
The Scale for the Assessment of Family Satisfaction contains 10 items, and an example of an item would be: 'How satisfied are you with the care family members show each other?

All the scales in FACES IV are linear, of the Likert type from 1 to 5, so that higher scores show greater expression of the measured dimension.

\section{SAMPLE}

The sample consisted of respondents aged 18-25, all of whom were students of the Faculty of Philosophy in Niš and Skopje. The average household income in the Serbian sample is around 40000 dinars, while in the Macedonian sample it is 35000 denars. The structure of the sample according to gender and place of residence is given in the following table.

Table 1 The structure of the sample according to gender and country

\begin{tabular}{lccc}
\hline Country & Male & Female & Total \\
\hline Macedonia & 17 & 82 & 99 \\
Serbia & 43 & 108 & 151 \\
Total & 60 & 190 & 250 \\
\hline
\end{tabular}

The total number of respondents in this research was 250. A larger part of the sample (151 respondents) lived in Serbia, and 99 respondents were from Macedonia. Regarding gender and considering the entire sample, there were more female respondents, 190 in total, compared to 60 male respondents.

\section{RESULTS}

The results of the descriptive statistics are given in Table 2.

Table 2 Descriptive statistics

\begin{tabular}{lllll}
\hline & MIN & MAX & M & SD \\
\hline Balanced cohesion & 1.57 & 5 & 3.91 & 0.67 \\
Balanced flexibility & 1.43 & 4.86 & 3.48 & 0.58 \\
Disengaged & 1.14 & 4.43 & 2.47 & 0.59 \\
Enmeshed (entangled) & 1.29 & 4.43 & 2.6 & 0.55 \\
Rigid & 1.14 & 4.14 & 2.6 & 0.55 \\
Chaotic & 1.14 & 4.29 & 2.5 & 0.53 \\
Family communication & 1.1 & 5 & 3.73 & 0.78 \\
Family satisfaction & 1.1 & 5 & 3.62 & 0.78 \\
Self-silencing & 1.48 & 4.64 & 2.65 & 0.51 \\
\hline
\end{tabular}

The obtained results for the entire sample show that the respondents mostly assessed family relations as balanced cohesion $(\mathrm{M}=3.91)$ and balanced flexibility $(\mathrm{M}=3.48)$. According to the Circumplex Model, the balanced levels of cohesion and flexibility are exactly the ones that are the most optimal for family functioning. The scores on all the 
unbalanced scales, which reflect both extremely high and extremely low cohesion and flexibility, were significantly lower and ranged between $M=2.47$ and $M=2.60$. Satisfaction with family communication was above the average theoretical value on a scale from 1 to 5 , and it was 3.73, whereas family satisfaction was 3.62 (on a scale from 1 to 5). The scores on self-silencing were grouped around the middle values on a scale from 1 to 5 , and the arithmetic mean was 2.65 . This result is similar to the result of a study, in which the empirical testing of the construct of self-silencing was performed, where, in two samples, the $\mathrm{M}$ of self-silencing was 2.78 and 2.82 (Nekić, Lacković-Grgin i Penezić 2004).

\subsection{Results of the relationship between self-silencing and family functioning}

The central part of this research is related to investigation of the relationship between self-silencing and family relations estimated with the FACES IV scale that measures family cohesion, flexibility, satisfaction with the communication among family members and satisfaction with the family in general. The results show that self-silencing is in a positive correlation with unbalanced levels of cohesion, with disengaged family relations $(\mathrm{r}=.195, \mathrm{p}=.002)$ and with enmeshed (entangled) family relations $(\mathrm{r}=.332, \mathrm{p}=.000)$. Also, self-silencing is in a positive correlation with unbalanced levels of flexibility, with rigid family relations $(\mathrm{r}=.243, \mathrm{p}=.000)$ and chaotic family relations $(\mathrm{r}=.217, \mathrm{p}=.001)$.

Such results confirm once again that moderate levels of cohesion and flexibility are the most optimal for the healthy functioning of family members, which is confirmed by the absence of correlations between balanced levels of cohesion and flexibility and selfsilencing. Self-silencing implies that a person hides his/her own opinions, feelings and needs - and that is not the most optimal pattern of behavior for the functioning of every individual. Correlations between self-silencing and satisfaction with communication and family in general were not statistically relevant.

\subsection{Results of the relationship between the dimensions of family functioning and socio-demographic variables}

On the entire sample, we analyzed whether there are differences in the perception of family relations between females and males. The results show that the females assessed family relations as more chaotic $(\mathrm{t}=-2.371, \mathrm{p}=.019)$ and more enmeshed in relation to the males ( $\mathrm{t}=-2.211, \mathrm{p}=.028)$. That would mean that the females perceived family relations as very flexible, without strict rules and roles, and that they perceived higher closeness and emotional connection between family members in relation to the males. It may be said that the females assessed their families as less hierarchically organized and rigid in terms of rules, but as being emotionally connected in a stronger manner in relation to the perception of the males in the studied sample.

Regarding other socio-demographic variables, we assessed whether the perception of family relations would be different in Serbian and Macedonian respondents. The results show that Macedonian students assessed family relations as more enmeshed in relation to Serbian students $(\mathrm{t}=6.396, \mathrm{p}=.000)$. That would mean that Macedonian students perceived the relations among family members as warmer, and with more emotional exchange in relation to Serbian students. On the other hand, Serbian students showed a higher level of satisfaction with their family in general than the Macedonian students $(t=-2.164, p=.031)$. This scale is related to the general assessment of family functioning and it contains 
elements for the assessment of family cohesion, flexibility and communication among family members.

In this paper, we investigated whether the perception of family relations would differ in relation to household income, and we did not confirm this assumption.

\section{DISCUSSION OF THE RESULTS}

Starting from the main hypothesis of the Circumplex Model that the balanced levels of cohesion and flexibility (from the low to the high level) are the most appropriate for a healthy family functioning and the satisfaction of their members, as well as that unbalanced levels of cohesion and flexibility (a very low and a very high level) are associated with problematic family functioning, we may say that our results confirm this assumption because self-silencing may be seen as a problematic functioning of family members. According to the theoretical model of Dana Jack (1991), people tend to display self-silencing in order to maintain close and harmonic relations with important persons, and they do so by hiding their true needs and desires. On the other hand, the suppression of one's own needs is related to depression and lower self-respect (Jack 1991; Thompson 1995; Thompson, Whiffen and Aube 2001). Research results show that the members of families with extremely low or extremely high cohesion and flexibility often hide their needs and desires in order to satisfy the needs of other family members. These unbalanced levels of cohesion and flexibility are in a negative correlation with the expression of personal needs and desires. Family relations dominated by a high level of entanglement of family members, mutual engagement and a lack of individuality contribute to a higher level of self-silencing of family members so that close family relations could be maintained. Similarly, self-silencing is also maintained in families with little emotional exchange, warmth and support between family members and in families where the individuality of the members is more pronounced in relation to their mutual connection.

Self-silencing is also prominent in families dominated by an extremely rigid division of mutual roles and responsibilities and where the power for making important decisions is in the hands of some of their members. What also contributes to the suppression of one's own opinions and feelings aimed at maintaining the existing close relations is the family system in which there are very little rules and mutual agreements, and where there are no established patterns of role division and behavior.

The construct of self-silencing is most frequently tested in relation to the partner reaction, and these results show that the self-silencing of women is also in a negative correlation with their satisfaction with their relationship and their estimations of how much their partners are satisfied with their partner relationship (Thompson 1995). There are almost no data on the relationship between self-silencing, functionality and satisfaction with family relations studied in a way we did in this research.

One of the goals of this research was to estimate family functioning in relation to different socio-demographic variables. The females in the analyzed sample assessed family relations as more enmeshed and more chaotic in relation to the males. We may also find such results in other studies and in different samples. In the research of Todorović and Simić (Todorović, Simić 2013) on a geographic cluster sample of 2053 respondents, the results point out that the females assessed a higher level of cohesion within the family than the males. Todorović and Matejević (Todorović i Matejević 2012), in the research of 
functionality of family relations on the sample of the students of the University of Niš, determined that the female students more frequently assessed family relations as balanced cohesion and flexibility in comparison to the male students.

The assessment of family functioning was also performed in relation to household income. Our starting assumption was that the perception of family functioning and general satisfaction with the family would differ depending on the amount of the income. The results show that the assessment of family functioning does not change depending on family income. Such a result is in accordance with a previous study conducted on a significantly larger sample (1826 respondents) which also did not find a correlation between the amount of the household income and the assessment of family functioning based on the Circumplex Model (Simić, Stojiljković i Todorović 2013).

When considering the differences in the perception of family relations between Macedonian and Serbian students, the results show that Macedonian students assessed family relations as more enmeshed in relation to Serbian students. Such results can be connected to the question of whether cross-cultural difference in the functioning of Macedonian and Serbian families, that is, whether a wider social context in Macedonia contributes in some way to a higher level of entanglement of family members, their higher interconnectedness and the fact that they are directed at one another. Although these two countries are the closest neighbors and they were a part of the same country for a long time, there remains an open question whether the accepted social and family values of the two countries are different and therefore reflected in some aspects of family functioning, such as mutual closeness of family members and the amount of exchange of feelings and emotional links. On the other hand, Serbian students expressed a generally higher family satisfaction. The Scale for the Assessment of Family Satisfaction consists of items that cover different segments of family functioning (cohesion, flexibility, mutual communication), so it can be concluded that Serbian respondents were more satisfied with their family climate. The results of other studies related to the individual characteristics of Macedonian and Serbian students also discuss potential cross-cultural differences.

In one of them, the authors came to the data that the current self-respect of Macedonian students is lower and that the depression symptoms are more prominent in relation to Serbian students (Todorović, Stojiljković i Arnaudova 2010). Although these differences are not given in the context of the link with family functioning, the obtained results from our and this research impose a need to check such connections, because the family context is very important both for self-respect and for the depression of family members.

\section{CONCLUSION}

The family is a very important social group for every individual. Family functioning can be significantly different from one family to another, and that will result in different functioning of their members. This research therefore discusses the connection between family functioning and the characteristics of family members. The family context dominated by an extremely high or extremely low flexibility and cohesion will result in a higher level of self-silencing of family members. That would mean that the members of such families will conceal their opinions and feelings, as well as their needs and desires in order to satisfy the needs of close persons and in order not to jeopardize their mutual relationship. Despite the fact that people behave in that way in order to maintain closeness and to keep the 
existing relations, self-silencing of one's own needs can, on the other hand, lead to a decrease in self-esteem and depression (Jack 1991). It is important to say that this paper confirmed the assumption of Olson and colleagues made in their theoretical Circumplex Model that balanced and moderate cohesion and flexibility are the most optimal for the healthy functioning of all the family members. Precisely balanced levels of cohesion and flexibility are the ones that do not correlate with self-silencing. Such family functioning is optimal so that family members can feel safe to express their own desires and needs without the fear that they can be judged and rejected because of that, or a fear that this would disturb their existing relationships in any way. Such a family system gives family members trust that their needs will be respected and that other family members will not reject them for being open regarding their desires and feelings.

On tested sample evaluated in terms of family functioning, the highest scores were found on balanced scales of cohesion and flexibility. Cohesion is the highest and closer to valuation 4. Satisfaction with the family is not that highly rated, as well as flexibility, which is seen as a state that family cohesion is more pronounced than the respondents would like it to be, which points to the quality of complication among family members. It should be borne in mind that is the sample was extracted from a population of students who prefer a higher degree of independence and freedom than the temporary family incomes enable them. On the other hand, in all the studies on cohesion, it is emphasized that functional families have a slightly higher level of cohesion than the arithmetic average; therefore, we can conclude that the families in our sample are mostly functional and balanced. Because of this reason, it might be said that respondents come from families which function very well. Still, the respondents from the Macedonian part of the sample estimate their family relation as being more complicated than the respondents from the Serbian sample. It does not necessarily mean worse family functioning, but may reflect certain social and family values that promote the closeness and togetherness of family members.

Acknowledgement: Prepared as a part of the project 179002, supported by the Ministry of Education and Science of the Republic of Serbia.

\section{REFERENCES}

Jack, Dana Crowley. Silencing the Self: Women and Depression. Cambridge: Harvard University Press. 1991.

Jack, Dana Crowley and Ali Alicha. "Introduction: Culture, Self-Silencing, and Depression: A Contextualrelational Perspective". In Silencing the Self Across Cultures. Depression and Gender in the Social World edited by Dana Crowley Jack and Alicha Ali, 3-17. Oxford University Press, 2010.

Jack, Dana Crowley and Diana Dill. "The Silencing the Self Scale. Schemas of Intimacy Associated with Depression in Women". Psychology of Women Quarterly 16, 1 (1992): 97-106. Available at: http://journals.sagepub.com.proxy.kobson.nb.rs:2048/doi/pdf/10.1111/j.1471-6402.1992.tb00242.x

Matejević Marina and JelisavetaTodorović. Funkcionalnost porodičnih odnosa i kompetentno roditeljstvo. Niš: Filozofski fakultet u Nišu, 2012.

Milojković, Marklena, Jelena Srna i Radmila Mićović. Porodična terapija. Beograd: Centar za brak i porodicu, 1997.

Goldner Vukov, Mila. Porodica u krizi. Beograd i Zagreb: Medicinska knjiga, 1988.

Mitić, Marija. Porodica i stres. Beograd: Institut za psihologiju, 1997.

Nekić, Marina, Katica Lacković-Grgin i Zvjezdan Penezić. "Skala samostišavanja". U Zbirka psiholoških skala i upitnika. svezak 2, uredili Ana Proroković, Katica Lacković-Grgin, Vera Ćubela, Adorići i Zvjezdan Penezić. Zadar: Filozofski fakultet u Zadru, 2004.

Olson, David. "Faces IV and the Circumpex Model: Validation Study". Journal of Marital \& Family Therapy 37, 1 (2011): 64-80. DOI: 10.1111/j.1752-0606.2009.00175.x 
Olson, David. "Circumplex Model VII: Validation Studies and Faces III”. Family process 25 (1986): $337-351$. DOI: $10.1111 /$ j.1545-5300.1986.00337.x

Olson, David and Dean Gorall. FACES IV \& the Circumplex Model. Roseville: Life Innovations, Inc, 2006. http://www.societyofpediatricpsychology.org/sites/default/files/files/3_innovations.pdf

Olson David, Gorall, Dean and Judy Tiesel. Faces IV paket. Priručnik za primenu (prevod preuzet od asocijacije porodičnih psihoterapeuta Srbije), 2016

Perosa, Linda and Sandra Perosa. "Adolescent Perceptions of Cohesion, Adaptability, and Communication: Revisiting the Circumplex Model". The Family Journal 9, 4 (2001): 407-419. Available at: http://journals.sagepub.com.proxy.kobson.nb.rs:2048/doi/pdf/10.1177/1066480701094008

Simić Ivana, Snežana Stojiljković i Jelisaveta Todorović. "Doživljaj porodičnih odnosa, empatija i novčani prihodi porodice". Teme 13, 2 (2013): 721-734. Available at: http://teme2.junis.ni.ac.rs/public/journals/1/ previousissues/teme2-2013/teme\%202-2013-13.pdf

Thompson, Janice. "Silencing the Self. Depressive Symptomatology and Close Relationships". Psychology of Women Quarterly 19, 3 (1995): 337-353. Available at: http://journals.sagepub.com.proxy.kobson.nb.rs: 2048/doi/pdf/10.1111/j.1471-6402.1995.tb00079.x

Thompson, Janice, Valerie Whiffen, and Jennifer Aube. "Does Self Silencing Link Perceptions of Care from Parents and Partners with Depressive Symptoms". Journal of Social and Personal Relationships 18, 4 (2001): 503-513. Available at: http://journals.sagepub.com.proxy.kobson.nb.rs:2048/doi/pdf/10.1177/0265407501184004

Todorović, Jelisaveta i Ivana Simić. "Dimenzije porodičnog odnosa, subjektivno blagostanje i tip domaćinstva". U Humanizacija univerziteta, uredila Bojana Dimitrijević, 298-311. Niš: Filozofski fakultet u Nišu, 2013.

Todorović, Jelisaveta, Snežana Stojiljković i Violeta Arnaudova. "Samopoštovanje i simptomi depresivnosti kod srpskih i makedonskih studenata". U Obrazovanje, ličnosti rad, uredile Snežana Stojiljković, Tatjana Stefanović-Stanojević i Zorica Marković, 5-20. Niš: Filozofski fakultet u Nišu, 2010.

Zotović Marija, Tijana, Telečki Ivana Mihić and Jelena Petrović. "Relacije karakteristika porodice I prevladavanja stresa kod adolescenata". Primenjena psihologija 1, 3-4 (2008): 145-160. Available at: http://psihologija.ff.uns.ac.rs/primenjena/clanci/20083-4145.pdf

\section{PORODIČNO FUNKCIONISANJE I SAMOSTIŠAVANJE STUDENATA DRUŠTVENO HUMANISTIČKIH NAUKA}

Polazeći od glavne hipoteze Circumplex modela, da su balansirani nivoi kohezije $i$ fleksibilnosti najpodesniji za zdravo porodično funkcionisanje, a da su nebalansirani nivoi kohezije i fleksibilnosti povezani sa problematičnim porodičnim funkcionisanjem, u ovom radu želeli smo da ispitamo na koji način su ove dimenzije porodičnog funkcionisanja povezane sa samostišavanjem. Kohezija se prema ovom modelu definiše kao emocionalna veza između članova porodice, a fleksibilnost kao kvaliteti ekspresija vođstva i organizacije. Samostišavanje se odnosi na kognitivnu šemu kreiranja i održavanja intimnog odnosa na način da osoba bude pasivna, da potiskuje svoja osećanja, mišljenje i delovanje, kako bi zadovoljila potrebe bliskih osoba.

Istraživanje je sprovedeno na uzorku srpskih i makedonskih studenata, ukupno 250. Korišćeni instrumenti bili su skala samostišavanja FACES IV, koju čine tri skale za merenje dimenzije kohezije (dezangažovanost, balansirana kohezija $i$ zapletenosti), tri skale za merenje dimenzije fleksibilnosti (rigidnost, balansirana fleksibilnost $i$ haotičnost), skala za procenu komunikacije, koja se definiše kao veština pozitivne komunikacije i posmatra se kao olakšavajuća dimenzija, i pomaže porodicama da promene njihove nivoe kohezije i fleksibilnosti, $i$ skala za procenu zadovoljstva porodicom.

Samostišavanje je u pozitivnoj korelaciji sa nebalansiranim nivoima kohezije, sa dezangažovanim poridičnim odnosima $(r=.195, p=.002) i$ sa zapletenim porodičnim odnosima $(r=.332, p=.000)$. Samostišavanje je u pozitivnoj korelaciji sa nebalansiranim nivoima fleksibilnosti, sa rigidnim porodičnim odnosima $(r=.243, p=.000)$ i haotičnim $(r=.217, p=.001)$.

Balansirani nivo kohezije, kao pokazatelj zdravog porodičnog funkcionisanja, povezan je sa nižim samostišavanjem članova porodice, odnosno, u takvim porodicama članovi porodice mogu otvoreno govoriti o svojim potrebama, osećanjima i mislima, bez straha da će to ugroziti potrebe drugih njenih članova. U porodicama u kojima preovladava izrazito niska ili izrazito visoka kohezivnost i fleksibilnost, članovi porodice prikrivaju svoje potrebe i želje kako bi zadovoljili potrebe njenih drugih članova.

Ključne reči: porodica, kohezija, fleksibilnost, samostišavanje, studenti. 